$\xi \ldots$

\title{
Dimethylnitrosamine (DMN) pre-treated rats and protective effect of Vernonia amygdalina post-treatment on liver function
}

\author{
Usunobun Usunomena ${ }^{1}$, Anyanwu Gabriel $\mathrm{O}^{2}$ \\ ${ }^{I}$ Department of Basic Sciences (Biochemistry Unit), Faculty of Basic and Applied Sciences, Benson, Idahosa University, \\ P.M.B. 1100, Benin City, Edo state, Nigeria \\ ${ }^{2}$ Department of Biochemistry, Bingham University, Karu, Nasarawa State, Nigeria \\ *Corresponding author E-mail:uusunobun@biu.edu.ng
}

\begin{abstract}
Background: Liver disease and toxicity is common, especially with many drug treatments. The effect of Vernonia amygdalina ethanolic leaf extract post-treatment on rats pre-treated with dimethylnitrosamine (DMN) was evaluated.

Methods: Male wistar rats were orally administered DMN (single dose of $25 \mathrm{mg} / \mathrm{kg}$ ) on first day and thereafter post-treated with $100 \mathrm{and}$ $200 \mathrm{mg} / \mathrm{kg}$ ethanolic leaf extract of Vernonia amygdalina for seven days. Analysis of serum concentrations of albumin, total protein, total bilirubin and glucose were carried out.

Results: Administration of DMN alone to rats significantly increased glucose and total bilirubin concentration $(\mathrm{P}<0.05)$ in the serum while it significantly reduced $(\mathrm{P}<0.05)$ serum total protein and albumin concentrations when compared with controls. However, posttreatment of DMN administered rats with 100 and $200 \mathrm{mg} / \mathrm{kg}$ ethanolic extract leaf of Vernonia amygdalina significantly $(\mathrm{P}<0.05)$ reversed these changes in a concentration dependent manner.

Conclusion: In conclusion ethanolic leaf extract of Vernonia amygdalina have a potent hypoglycaemic and hepatoprotective action against dimethylnitrosamine-induced liver damage in rats may be due to its antioxidant properties..
\end{abstract}

Keywords: Dimethylnitrosamine; Pre-treatment; Post-treatment; Vernonia amygdalina.

\section{Introduction}

Dimethylnitrosamine (DMN) is a potent hepatotoxin, mutagen and carcinogen (Usunobun et al. 2015), whose exposure may happen in large number of places including industries such as tanneries, pesticide manufacturing plant, rubber and tire manufacturing plants, alkylamine manufacture/use industries, fish processing industries, foundries, and dye manufacturing plants (Mitch et al. 2003).

Vernonia amygdalina, commonly known as bitter leaf, is reputed to have several health benefit against amoebic dysentery (Moundipa et al. 2005), gastrointestinal disorders (Akah \& Ekekwe 1995), antimicrobial and antiparasitic activities (Akinpelu 1999; Hladik et al. 2005). Vernonia amygdalina have been reported to contain saponins, alkaloids, tannins, steroids, terpenes, coumanns, flavonoids, phenolic acid, lignans, and xanthones (Muraina et al.2010, Usunobun \& Okolie 2015), edotides (Izevbigie 2003) and sequiterpenes (Kupchan et al. 1969). This study was undertaken to determine the effect of ethanolic leaf of Vernonia amygdalina post-treatment on liver synthetic molecules and glucose in rats pre-treated with an acute single dose of DMN.

\section{Materials and methods}

2.1. Collection, identification, preparation and extraction of Vernonia amygdalina leaves
Fresh mature leaves of Vernonia amygdalina were obtained from a garden in Ikpoba Hill, Benin City, Edo state. The leaves were identified, sorted, washed and air dried at room temperature and milled into powder and weighed $(1500 \mathrm{~g})$. Three (3) litres of absolute ethanol was added to the powdered sample and allowed to stand for 48hours. It was filtered using filter paper and re-filtered using cotton wool to ensure purity. The ethanol extract was reduced to one-tenth by rotary evaporator at $40^{\circ} \mathrm{C}$. The extract was further evaporated to dryness at $37^{\circ} \mathrm{C}$ in water bath. The extract was stored in a well-sealed container and kept in a refrigerator at $4^{\circ} \mathrm{c}$ to protect it from light and moisture till it was used.

\subsection{Experimental animals and administration}

Adult male albino rats weighing 140-200g were purchased from Anatomy Department, College of Basic Medical Sciences, University of Benin for the experiment. They were allowed to acclimatize for 7 days and maintained under standard photoperiodic conditions and kept in the animal house of the Department of Biochemistry, Faculty of Basic and Applied sciences, Benson Idahosa University. The animals were provided standard pellet diet and water ad libitum. The DMN used in this work was synthesized according to the method of Vogel (1971). Administration of extract and DMN was orally using gavage and was done between 9.00am-10.00am

A total of thirty male rats were assigned into one of the following groups: Group 1 (control) received distilled water, Group 2 received $100 \mathrm{mg} / \mathrm{kg}$ Vernonia amygdalina only for seven days. Group 3 received a single dose of DMN only $(25 \mathrm{mg} / \mathrm{kg})$ on the first day. Group 4 received a single dose of DMN $(25 \mathrm{mg} / \mathrm{kg})$ on 
day 1 and also Vernonia amygdalina $(100 \mathrm{mg} / \mathrm{kg}$ ) for seven days. Group 5 received a single dose of DMN $(25 \mathrm{mg} / \mathrm{kg})$ on day 1 and also Vernonia amygdalina $(200 \mathrm{mg} / \mathrm{kg})$ for seven days. $24 \mathrm{hrs}$ after last administration, rats from each group were sacrificed by cervical dislocation. Blood samples were obtained through heart puncture via a syringe into a plain sterile bottles (for serum) and were allowed to stand for one hour to clot and thereafter centrifuged at $3000 \mathrm{rpm}$ for 45 minutes at room temperature to obtain serum for biochemical analysis.

\subsection{Biochemical parameters}

Serum albumin, total protein, total bilirubin and glucosewere determined by using the RANDOX Kit according to themanufacturer's instructions

\subsection{Statistical analysis}

Data obtained from this study were expressed as mean value \pm standard deviation. Differences between means of control and tested groups were determined by One way ANOVA using Statis- tical Package for social scientist (SPSS). A probability level of less than $5 \%(\mathrm{p}<0.05)$ was considered significant

\section{Results}

As it is shown from figure 1-4, the level of total protein and albumin were significantly decreased in rats treated with DMN alone compared to control and extract treated rats. Furthermore, the total bilirubin and glucose of DMN-pre-treated rats were statistically increased in comparison to control and other treated groups.

However in rats post-treated with $100 \mathrm{mg} / \mathrm{kg}$ and $200 \mathrm{mg} / \mathrm{kg}$ Vernonia amygdalina ethanolic leaf extract after DMN administration, the levels of total protein and albumin were significantly increased in concentration dependent manner compared to DMN alone administered rats. Also in rats post-treated with $100 \mathrm{mg} / \mathrm{kg}$ and $200 \mathrm{mg} / \mathrm{kg}$ Vernonia amygdalina, after DMN administration, the total bilirubin and glucose were statistically decreased compared to DMN alone rats.

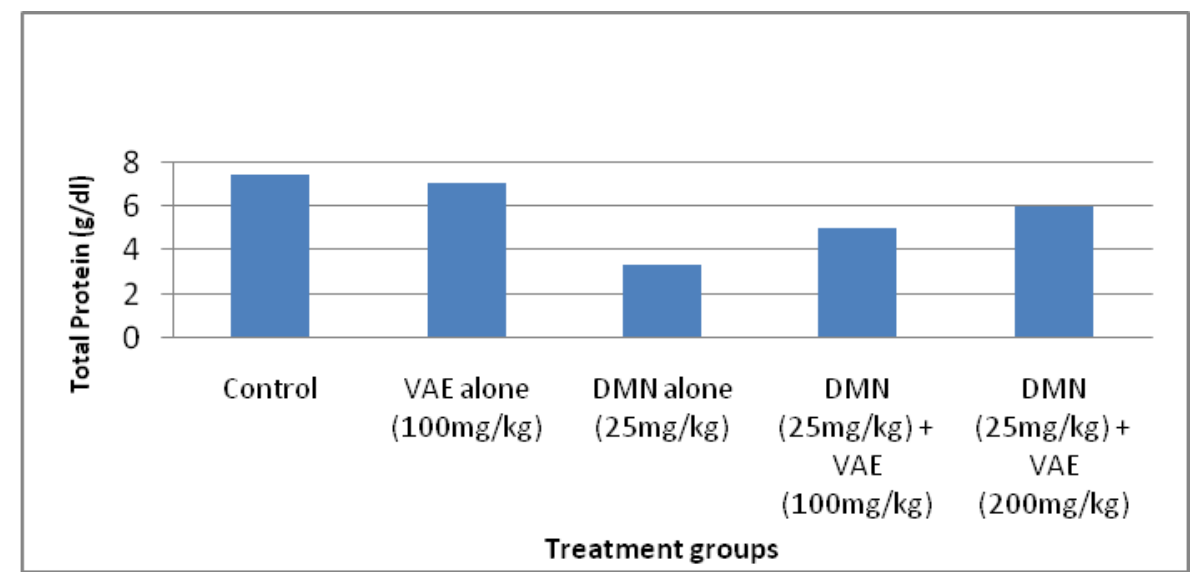

Fig. 1: Effect of Vernonia amygdalina Post-treatment on Total Protein in DMN-Pre-treated Rats.

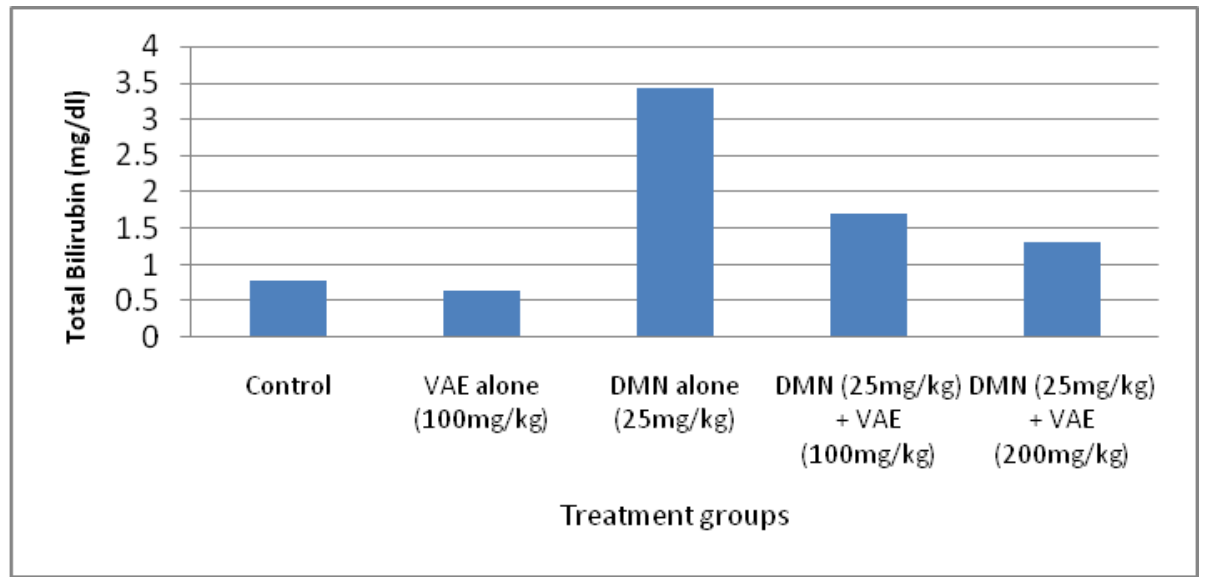

Fig. 2: Effect of Vernonia amygdalina Post-treatment on Total Bilirubin in DMN-Pre-treated Rats. 


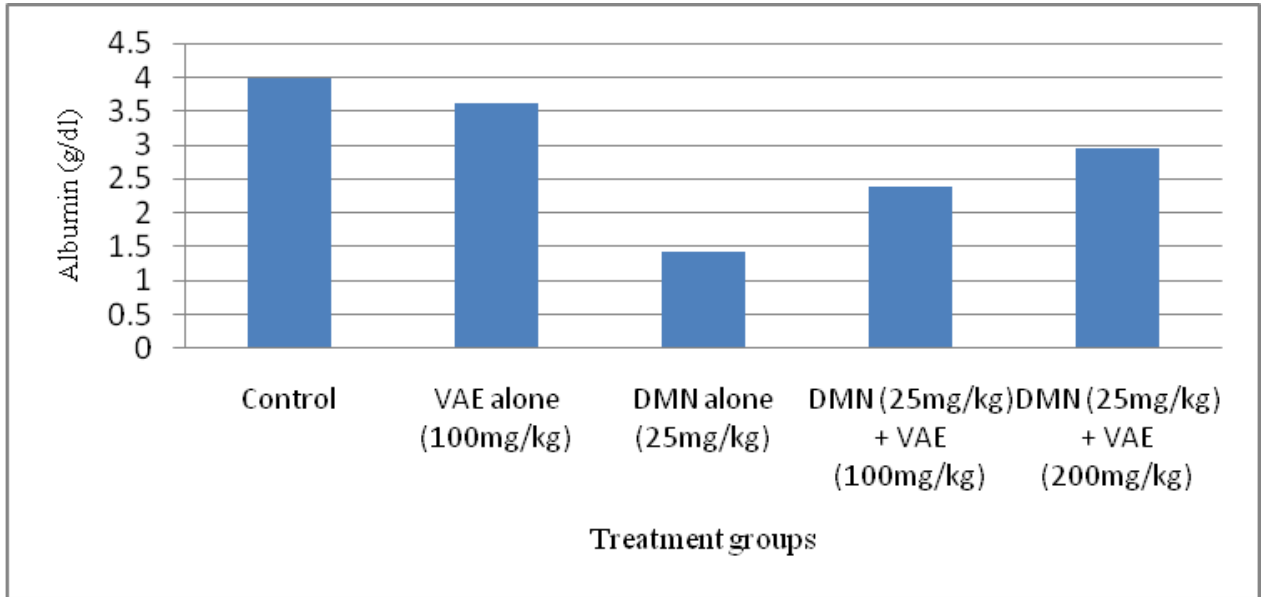

Fig. 3: Effect of Vernonia amygdalina Post-treatment on Albumin in DMN-Pre-treated Rats.

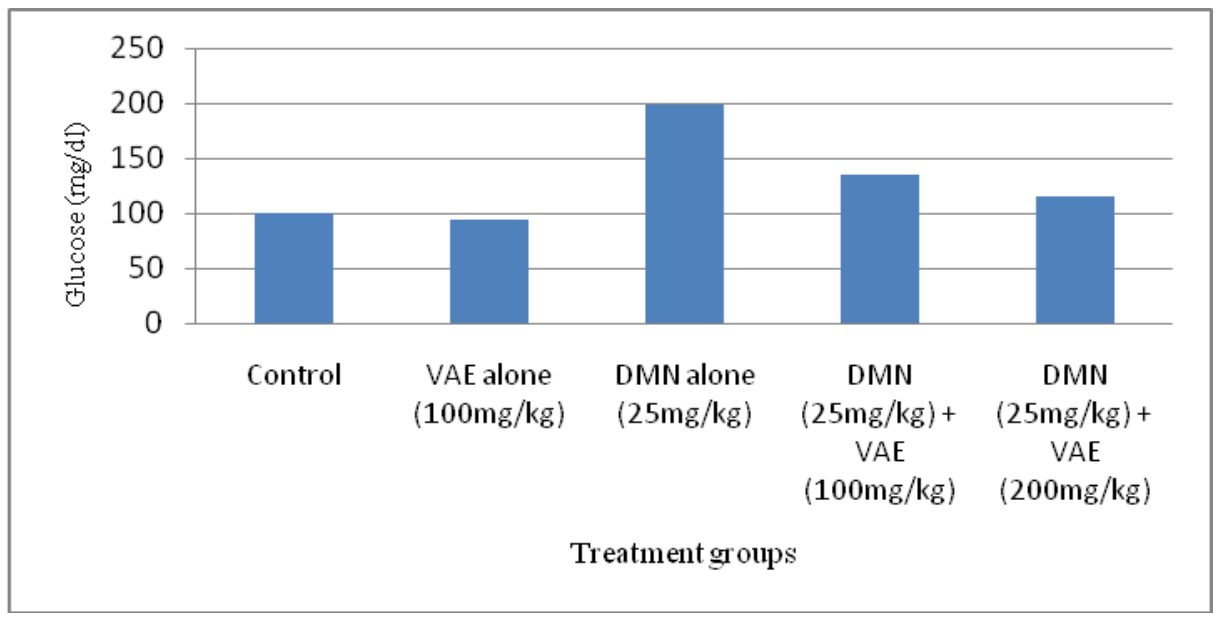

Fig. 4: Effect of Vernonia amygdalina Post-treatment on Serum Glucose in DMN-Pre-treated Rats.

\section{Discussion}

Medicinal plants have been used as traditional treatment for numerous human diseases for thousands of years in many parts of the world. In rural areas of developing countries, herbal materials continue to be used as the primary source of medicines (Chitme et al. 2003). The present study revealed that administration of 25 $\mathrm{mg} / \mathrm{kg}$ DMN induced hepatotoxicity manifested biochemically by a significant increase of serum glucose and bilirubin concentration in addition to a significant decrease in serum total protein and albumin. The liver is the key site of metabolism of xenobiotics and also plays a role in synthesis of albumin. Liver malfunction will impair its synthetic role and could have led to decreased levels of albumin in serum as observed in DMN administered rats in this study. The administration of DMN alone may have adversely interfere with protein metabolism probably by inhibiting the synthesis of proteins such as albumin in the liver. The decrease in serum protein may be due to changes in protein and free aminoacids and their synthesis in the injured liver cells and/ or increased protein degradation. However, post-treatment with $100 \mathrm{mg} / \mathrm{kg}$ and $200 \mathrm{mg} / \mathrm{kg}$ Vernonia amygdalina significantly $(\mathrm{p}<0.05)$ reversed these changes, maybe by increasing protein synthesis. This indicates the hepatoprotective activity of Vernonia amygdalina leaves against damage by DMN. Stimulation of protein synthesis has been advanced as a contributory hepatoprotective mechanism which accelerates regeneration of cells (Awang 1993).

Bilirubin is the main bile pigment that is formed from the breakdown of heme in the red blood cells. It is transported to the liver where it is secreted by the liver into the bile. Conjugation of bilirubin is a prerequisite for its excretion into the bile (Nelson \& Cox 2000). Malfunctioning of the liver was evidenced by the significant increase $(p<0.05)$ in the level of total bilirubin in the serum of the group treated with DMN when compared with control and extract treated groups (Figure 2). Increase in the level of total bilirubin in the blood may result from a defect in the function of the liver to conjugate the bilirubin being produced (Marks \& Dennis 1996). The increase in serum total bilirubin may also be due bile ductules blockage as a result of inflammation as well as conjugated bilirubin regurgitation from the necrotic hepatocytes to sinusoids. The concentration dependent significant reduction $(\mathrm{p}<0.05)$ of total bilirubin level upon post-treatment with $100 \mathrm{mg} / \mathrm{kg}$ and $200 \mathrm{mg} / \mathrm{kg}$ Vernonia amygdalina indicates that the conjugating function of the liver was improved. The reduction of the total bilirubin level by the extracts suggests that Vernonia amygdalina may activate constitutive androstane receptor (CAR) which is a key regulator in bilirubin clearance in the liver. The primary function of CAR in the bilirubin clearance pathway is to direct a coordinate response to elevated levels of bilirubin by increasing the hepatic expression of each component of the pathway (Moore et al. 2004). Thus the ability of Vernonia amygdalina post-treatmentto significantly reduce $(\mathrm{p}<0.05)$ the level of total bilirubin when compared with DMN - treated group suggests the potential of the Vernonia amygdalina in clearing bilirubin from the serum when its level is elevated.

Also in this study, administering DMN to rats resulted in a statistically significant increase of serum glucose levels. The progressive accumulation of glucose revealed that rats exposed to DMN may become hyperglycemic. Hyperglycemia is usually associated with insulin resistance during gastrointestinal cancers and in the present study, it is possible that the observed increase in glucose levels could be due to the toxicity caused to the pancreatic islet cells and due to the alteration in carbohydrate metabolism by the administration of DMN. The hyperglycemia observed in the present results might be due to reduced insulin availability. Furthermore, with regards to the fact that DMN has increased serum glucose level, it could be suggested that DMN prevented the influx of 
glucose into the cells of peripheral tissues. Increased blood glucose concentration results from an imbalance between the hepatic output of glucose and the peripheral uptake of the sugar (Coles 1980). However, the significant reduction in glucose levels observed in groups receiving $100 \mathrm{~m} / \mathrm{kg}$ and $200 \mathrm{mg} / \mathrm{kg}$ Vernonia amygdalina maybe due to the activity of its bioactive principles such as flavonoids, saponins and alkaloids (Usunobun \& Okolie 2015; 2016).

The findings in this study point to the fact that Vernonia amygdalina is hypoglycaemic and hepatoprotective against DMN- induced liver damage. Hence it is possible that a probable mechanism of hypoglycaemic and hepatoprotection against DMN- induced damage is the antioxidant activity as our studies have shown the presence of alkaloids, saponins, tannins, flavonoids and polyphenols in Vernonia amygdalina leaves.

\section{References}

[1] Akah PA \& Ekekwe RK. (1995). Ethnopharmacology of some of the asteraceae family used in the Nigerian traditional medicine. Fitoterapia 66, 352-355.

[2] Akinpelu DA (1999). Antimicrobial activity of Vernonia amygdalina leaves. Fitoterapia, 70, 232-234. http://dx.doi.org/10.1016/s0367-326x(99)00061-1.

[3] Awang D (1993). Milk Thistle. Can. Pharm. J. 23, 749-754.

[4] Chitme HR, Chandra R., \& Kaushik S (2003). Studies on antidiarrheal activity of Caltropis gigantean R. BR. In experimental animals. Journal of Pharmacy and Pharmaceutical Science7, 70-75.

[5] Coles EH. (1980). Veterinary Clinical Pathology, 3rd ed, WB Saunders Co Philadelphia London Toronto pp. 255.

[6] Hladik C, Krief S. \& Haxaire C. (2005). Ethnomedicinal and bioactive properties of plants ingested by wild chimpanzee in Uganda.Journal of Ethnopharmacology101, 1-5. http: //dx.doi.org/10.1016/j.jep.2005.03.024.

[7] Izevbigie EB (2003). Discovery of water-soluble anticancer agents (edotides) from a Vegetable found in Benin City, Nigeria. Experimental Biology and Medicine 228, 293-298.

[8] Kupchan SM, Hemmingway RJ, Karim A. \& Werner D. (1969). Tumor inhibitors. XLVII Vernodalin and Vernomygdin. Two new cytotoxic sesquiterpene lactone from Vernonia amygdalina Del. Journal of organic Chemistry 34, 3908 - 3911. http://dx.doi.org/10.1021/jo01264a035.

[9] Marks MD., \& Dennis L. (1996). Jaundice. Available at www.medicine net.com.

[10] Mitch WA, Sharp JO, Trussell RR, Valentine RL, Alvarez-Cohen L. \& Sedlak DL. (2003). N-nitrosodimethylamine (NDMA) as a drinking water contaminant: a review. Environmental Engineering Science 20(5), 389-404. http://dx.doi.org/ $10 . \quad 1089$ /109287503768335896.

[11] Moore D, Jun Z, \& Werdong H (2004). Induction of bilirubin clearance by xenobiotic receptor CAR. Journal of Clinical Investigation 113, 137-143.

[12] Moundipa PF, Flore KGM, Bilong CFB, \& Bruchhaus I (2005). In vitro amoebicidal activity of some medicinal plants of the Bamun region(Cameroon). African Journal of Traditional. Complementary and Alternative Medicine 2, 113-121. http: //dx.doi.org/10.4314/ajtcam.v2i2.31109.

[13] Muraina IA, Adaudi AO, Kazeem HM, Picard J, McGaw LJ. \& Eloff JN. (2010). Antimycoplamal activity of some plant specie from northern Nigeria compared to the current used therapeutic agent. Pharmacological Biology 48, 1103-1107). http://dx.doi.org/10.3109/13880200903505633.

[14] Nelson DC, \& Cox MM (2000). Lehninger Principles of Biochemistry. $3^{\text {rd }}$ edition. Worth Publishers, USA, p. 842.

[15] Usunobun U. \& Okolie NP (2015). Phytochemical, trace and mineral composition of Vernonia amygdalina leaves. International Journal of Biological and Pharmaceutical Research 6(5), 393-399.

[16] Usunobun U. \& Okolie PN (2016). Phytochemical analysis an proximate composition of Vernonia amygdalina. International Journal of Scientific World 4 (1), 11-14 http: //dx.doi.org/10.14419/ijsw.v4i1.5845.

[17] Usunobun U, Okolie NP \& Eze IG (2015). Inhibitory Effect of Vernonia amygdalina on Dimethylnitrosamine (DMN)-induced Liver Fibrosis in Rats. International Journal of Clinical Pharmacology and Toxicology4(4), 179-184.
[18] Vogel AI (1971). A textbook of practical organic Chemistry including qualitative organic analysis. Longman group limited, London. Pp 426. 